\title{
Michael Bianco Inc. - Immigrant Workers To Save Costs
}

Lynn Ruggieri, Roger Williams University, USA

\begin{abstract}
Michael Bianco Inc. was a relatively small manufacturing firm employing 85 people in 2001. By 2004, the company was awarded several multimillion dollar government contracts from the Department of Defense making backpacks for troops serving in Iraq. The company increased its work force to over 500 to accommodate the contracts. The workers, however, were illegal aliens. The Department of Homeland Security raided the manufacturing facility, found and detained over 300 illegal workers for deportation. Further investigation revealed deplorable and unfair working conditions, including lack of heat and docking workers' pay for talking. Employees worked double shifts and instead of being paid overtime, they were paid straight time out of two separate companies. Humanitarian groups defended the workers and some later filed suit for back pay.
\end{abstract}

Keywords: ethics; immigration; fixed price contract

\section{INTRODUCTION}

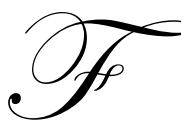

rancesco Insolia entered District Court located on the majestic Boston Harbor and paused at the inscription which read, "Justice is the great interest of man on earth; it is the ligament which holds civilized beings and civilized nations together." As he walked the corridors of this symbol of the American judicial system as old as the country itself, the walls seemed to echo with the hopes and struggles of the founding fathers and the immigrants that sought to call this county home.

The courthouse stood for everything he dreamed of when he emigrated from his native Italy to pursue the American dream. He had risked so much for a start at a new life. He worked hard and long hours and rose to own his own company, but was that rise too quick and at what cost? Francesco Insolia continued to reflect on the events of the last several years as he stood with the others in the courtroom and vaguely heard the words "all persons having anything to do before the Honorable Justice of the District Court, draw near, give your attendance, and you shall be heard. God save the Commonwealth of Massachusetts. The Court is now in session; please be seated." ${ }^{2}$

\section{BACKGROUND}

Michael Bianco Inc. was established by Francesco Insolia in 1985 as a privately held corporation in the state of Massachusetts. Located in New Bedford, Massachusetts, Michael Bianco Inc. manufactured high quality leather goods, including its own line of quality handbags and leather goods. Its product line included handbags, travel bags, back packs, business cases, as well as travel, and business and golf accessories for retailers.

The company expanded rapidly between 2001 and 2005 as it was awarded contracts from the U.S. Department of Defense. The company grew from 85 employees to more than 500 . The enormous influx of workers needed to be trained and trained quickly. The company applied for and received approximately $\$ 100,000$ in state grants through the Massachusetts Department of Work force Development to hire and train new stitchers and machine operators, and to develop an in-house training program for entry-level workers as part of the company's

\footnotetext{
${ }^{1}$ United States District Court, District of Massachusetts, retrieved from www.uscourts.gov June 25, 2007.

${ }^{2}$ Official call of the Court, Barnstable Clerk's Office
} 
expansion. The grant was awarded by the state on the promise that the company would hire additional workers. The state did not inquire as to whether the workers included illegal immigrants before it issued the grant.

The company also received a five-year tax break from the city of New Bedford in 2004 which amounted to $\$ 50,000$ for the first two years. The tax relief required that half of the new jobs generated would be awarded to city residents in exchange for $\$ 80,000$ in savings by the year 2010 . Neither the state nor city grants noted any restrictions on the type of workers that would be hired.

The city of New Bedford is located approximately 50 miles south of Boston and is the seventh largest city in the state of Massachusetts. New Bedford, located on the coast of Massachusetts, was known as The Whaling City because it was, at one time, a prominent port for the whaling industry. In 1841, Herman Melville shipped out aboard the whale ship, Acushnet, and his experiences inspired him to write Moby-Dick, in which he describes New Bedford in great detail.

The major industries of New Bedford, at the time, were whaling, manufacturing of fine cotton goods, and the general fisheries. By the early 1900's, New Bedford became one of the largest producers of cotton yarns and textiles in the country. New Bedford was also home to many large-scale factory operations for a variety of products, including rubber, metal, and glass manufacturing facilities. In recent years, New Bedford has seen most of the textile and manufacturing industries leave the state due to foreign competition. Exhibit 1 provides Census Bureau demographic information on the population, median household income, and unemployment rate for New Bedford, Massachusetts.

Exhibit 1: Available Work Force

\begin{tabular}{|l|c|}
\hline 2005 Census Bureau Statistics - New Bedford Massachusetts & \\
\hline Total Population & 84,898 \\
\hline Population Over 18 Years & 64,801 \\
\hline Population Over 65 & 12,522 \\
\hline Median Age & 37.1 \\
\hline In Labor Force Population & 42,030 \\
\hline Median Household Income & $\$ 31,845$ \\
\hline Unemployment Rate & $7.3 \%$ \\
\hline
\end{tabular}

Source: U.S. Census

\section{A NEW DIRECTION FOR MICHAEL BIANCO INC.}

Michael Bianco Inc. was originally a producer of leather products but saw the opportunity for expansion in the area of much-needed military products by the Federal government. Michael Bianco Inc. was awarded several Department of Defense contracts:

- $\quad$ April 2005 - a maximum \$36,138,154 firm-fixed-price, indefinite quantity contract for MOLLE equipment for the U.S. Army with a performance completion date of August 31, 2006

- $\quad$ Aug. 8, 2006 - a delivery order amount of $\$ 21,000,141$ as part of a $\$ 138,562,131$ firm-fixed-price contract with the Army Research, Development, and Engineering Command for the modular lightweight loadcarrying equipment systems expected to be completed by August 7, 2010

MOLLE is an abbreviation for Modular Lightweight Load-carrying Equipment. It is used to define the load-bearing equipment and rucksacks utilized by the United States Army and Marine troops serving in Afghanistan and Iraq. The system's modularity is derived from the use of pouch attachment webbing which consists of rows of heavy-duty nylon stitched onto the vest and allows for attachment of various MOLLE-compatible pouches and accessories. The soldiers use the backpacks to carry weapons, ammunition, and supplies. 
A firm-fixed-price contract provides for a price that is not subject to any adjustment on the basis of the contractor's costs in performing the contract. This type of contract places upon the contractor the risk and full responsibility for all costs and resulting profit or loss. It provides maximum incentive for the contractor to control costs and perform effectively. In contrast, a cost-plus contract is one in which the selling price is based on the total cost of production plus a percentage or fixed dollar amount.

\section{THE RAID}

On March 6, 2007, immigration agents executed a search warrant on the Michael Bianco Inc. production facility in New Bedford, Massachusetts. The raid on the manufacturing plant, known as Operation United Front, was conducted by the Department of Homeland Security and the U.S. Immigration and Customs Enforcement (ICE) in conjunction with Massachusetts state officials. The raid was the culmination of a long undercover criminal investigation by the U.S. Attorney's office in Boston, Massachusetts. The investigation centered on whether the owner of M. Bianco Inc., Francesco Insolia, knowingly and actively recruited illegal aliens.

The investigation was based on information provided to law enforcement by a cooperating witness, as well as an undercover investigation in which an ICE agent posed as an illegal alien and obtained work at Michael Bianco Inc. (MBI). It is alleged that Insolia and other MBI employees working on his behalf have knowingly and actively been hiring illegal aliens to fill their expanding work force. It is alleged that although MBI requires all prospective employees to produce proof of their identity and their eligibility to work, the company is aware that many employees have obtained fraudulent Alien Registration cards, commonly known as green cards, and Social Security cards. It is alleged that MBI management has even instructed prospective employees, including the undercover ICE agent, on how to obtain such fraudulent documents. ${ }^{3}$

According to the affidavits, it is alleged that the undercover ICE agent informed several MBI management level employees, including Insolia, she had come to the United States illegally from Mexico without papers. It is alleged that Ana Figueroa (MBI payroll manager) was one of two managers who informed the undercover ICE agent as to how she could purchase a fraudulent Social Security card. According to the affidavits, one fraudulent document source to whom the undercover ICE agent was directed, was Luis Torres. It is alleged that Torres, an MBI employee, supplied the undercover ICE agent with a fraudulent Alien Registration card and Social Security card for a fee of $\$ 120$.

On the day of the raid, workers described people bumping into sewing machines and tables in an effort to escape arrest and almost certain deportation. ${ }^{5}$ Workers stomped over fellow workers in the rush for the door and many were injured. The initial numbers were difficult to determine, but Immigration and Customs Enforcement detained hundreds of workers. The employees that did not have proper documentation were brought to Fort Devens, a military facility about 90 miles to the north, near Boston, for deportation processing, if applicable. At the scene of the raid, Richard Rocha of ICE stated, "We want to make sure that employers know that hiring people who are illegal is not something ICE will tolerate. We also want to make a point that these illegal workers are taking jobs away from people in New Bedford." Rosalina Jovel, a Salvadoran immigrant, countered, "People are working here. They are not stealing or doing drugs. They are not doing anything bad to the country. There are so many drug dealers around; why don't they go hunt them?"6

The Department of Defense maintains an office on site at Michael Bianco Inc. to oversee the work on products that are used by the Armed Forces. The representative at the facility inspects the gear used by the military; however, 'the contract language spells out that it is the manufacturer's responsibility, not the Army's, to ensure that undocumented immigrants are not employed at the plant., 7

\footnotetext{
${ }^{3}$ U.S. Department of Justice, United States Attorney Michael J. Sullivan District of Massachusetts, retrieved from www.usdoj.gov/usao/ma, June 12, 2007

${ }^{4}$ Id.

${ }^{5}$ Zinner, Karen Lee, Hundreds Nabbed in Raid. The Providence Journal (March 7, 2007) A1

${ }^{6} \mathrm{Id}$.

${ }^{7}$ Zinner, Karen Lee, Factory Raid Sparks Crisis for Families. The Providence Journal (March 8,
} 


\section{HUMANITARIAN OBJECTIONS}

Social service advocates and officials have decried a humanitarian crisis that has torn families apart and left dozens of children adrift while their parents remain in federal detention. Immigrant and social-service advocates said the raid left dozens of young children in the care of relatives, friends or volunteers. "These mothers need to be with their children. This is not a legal issue; this is a humanitarian issue", said Bethany Toure of the New Bedford Community Connections Agency. ${ }^{8}$

According to Paula Grenier, spokeswoman for the ICE, 60 detainees were released on humanitarian grounds, such as being a primary family caregiver, pregnancy, or medical/health issues. The spokeswoman additionally stated that no children were stranded and that the agency had coordinated with state officials so that those in custody were given the option of letting their children stay with a guardian or putting them in state care.

"Should the mothers not be returned, we will mobilize as a community for their release", Toure said at a news conference held at the Our Lady of Guadalupe at St. James Church. Carlos Miranda, 24, a construction worker from Honduras, was among those who spoke at the news conference. Miranda said his nine-month old daughter is so confused by her mother's absence. "My daughter is suffering a lot and will die without her mother at her side", said Miranda. He added that his girlfriend, Marisela Inestroza - who is the child's mother - remained with the other detainees at the Fort Devens detention center in central Massachusetts for not having proper work documents. ${ }^{9}$

\section{WORKING CONDITIONS}

Soon after the raid, workers who were released on humanitarian reasons began to speak out about the conditions in the facility. "The emergency door at the back was always locked. If the workers wiped their hands with toilet paper, owner Francesco Insolia fined them \$20. If they stayed too long in the bathroom, he came and got them. If they were a minute late, he charged them \$20. If they had a headache, he charged them 25 cents per Tylenol. We worked with no heat. He'd only turn it on for five minutes and there was cold air coming out; then he'd turn it off', said Norma Urbina, a worker at the textile company who was released on humanitarian grounds. ${ }^{10}$

The conditions allegedly include docking of pay by 15 minutes for every minute an employee is late; fining employees for spending more than two minutes in the restroom and firing for a subsequent infraction; providing one roll of toilet paper per restroom stall per day; fining employees $\$ 20$ for leaving the work area before the break bell sounds; and fining employees $\$ 20$ for talking while working and firing for a subsequent infraction. ${ }^{11}$

Cubias de Varels stated that she was injured on the job three months ago when a needle pierced her eyelid. "They sent me to the clinic and told me to report back to work the next day." Vilma Inestroza said that a Department of Defense inspector, who maintained an office at the factory, expressed sympathy for their working conditions and said that he would say he worked for the government, not Francesco. ${ }^{12}$ The inspector was responsible for ensuring that work at the manufacturing plant met federal standards.

\section{ANOTHER CORPORATE ENTITY}

As federal investigators continued, investigations records revealed a second corporate entity in Massachusetts, named Front Line Defense. The principals, listed per the Massachusetts Secretary of State, were Suzanne Thompson (Francesco Insolia's wife) as President, Secretary, and Treasurer and Marguerite Insolia as Director. According to a federal affidavit, Front Line appears to exist for internal accounting purposes at the Bianco plant.

${ }^{8} \mathrm{Id}$.

2007) A1

${ }^{9}$ Id.

${ }^{10}$ Zinner, Karen Lee, Jobs, but no Dignity. The Providence Journal (March 9, 2007) A1

${ }^{11}$ Zinner, Karen Lee, Hundreds Nabbed in Raid. The Providence Journal (March 7, 2007) A1

${ }^{12}$ Zinner, Karen Lee, Jobs, but no Dignity. The Providence Journal (March 9, 2007) A1 
A special agent described the time card system as, "MBI (Michael Bianco Inc.) employees submit MBI time cards for all work performed between 7:30 am and $5 \mathrm{pm} . " 13$ Workers testified that they clocked in using a fingerprint recognition device. "They placed their hands in the Bianco machines at 7:30 am and at 5 pm when they clocked out." $"$ The workers that worked more than one shift continued to explain, "At 5:15, we punched in the other one (referring to the Front Line Defense time clock) and worked until 11 pm." Workers continued to testify that they would punch out of one time clock and into another and that they received two separate paychecks. Tejas said she performed the same job in her same seat for both shifts, but her paychecks showed she worked straight time for two companies - Michael Bianco Inc. and Front Line Defense Inc. - one work station; same work; two paychecks; no overtime. ${ }^{15}$ Exhibit 2 provides the federal law regarding payment of overtime hours worked.

Exhibit 2: Computation Of Overtime Pay

Fair Labor Standards Act provides:

Unless specifically exempted, employees covered by the Act must receive overtime pay for hours worked in excess of 40 in a workweek at a rate not less than time and one-half their regular rates of pay.

Source: 29 U.S.C $\S 203$

\section{WHY TOLERATE THE CONDITIONS}

The interviewed workers stated that they received $\$ 7.50$ an hour and for a 40-hour week earned a paycheck of \$279. Workers did receive overtime for working on Saturday, but the separate checks received from MBI and Front Line Defense reflected straight time. Several workers were asked why they tolerated the conditions and they replied they were aware of the sweatshop conditions at the plant, but say they were treated far worse at a sweater factory in El Salvador. ${ }^{16}$ In El Salvador, the average wage rate per hour is $\$ 1.51$. In 2004, while $48 \%$ of the El Salvadorans lived in poverty, $19 \%$ lived in extreme poverty.

Gross payroll is the amount of wages earned per hour for the number of hours worked - in this case, $\$ 300.00$. The amount of net wages that a worker receives is gross wages less applicable Federal and State payroll taxes.

Payroll taxes are the State and Federal taxes employers are required to withhold and/or to pay on behalf of employees. Employers are required to withhold State and Federal income taxes as well as Social Security and Medicare taxes. In addition, an employer is required to pay a matching amount of Social Security and Medicare taxes for employees and to pay State and Federal Unemployment tax. Exhibit 3 provides the applicable taxes and rates for the payroll taxes due by an employer.

Exhibit 3: The Payment of Payroll Taxes

The Social Security tax rate is $6.2 \%$. An employer is required to withhold $6.2 \%$ of an employee's wages for Social Security taxes and to pay a matching amount in Social Security taxes until the employee reaches the wage base for the year.

The Medicare tax rate is $2.9 \%$ for the employee and the employer. Employers must withhold $1.45 \%$ of an employee's wages and pay a matching amount for Medicare tax.

The employer also must pay State and Federal Unemployment Taxes (SUTA and FUTA). The FUTA rate is $6.2 \%$, but there is a credit of up to $5.4 \%$ for SUTA taxes paid. If a company is eligible for the maximum credit, the FUTA rate will be $0.8 \%$. The SUTA tax rate is based on the amount of unemployment claims that are filed by terminated employees and will fluctuate yearly. The average rate in Massachusetts is $6.04 \%$.

Source: IRS Publication 15 Circular E and www.mass.gov

\footnotetext{
${ }^{13}$ Zinner, Karen Lee, Bianco Workers Allege Violations. The Providence Journal (March 28, 2007) A1

${ }^{14} \mathrm{Id}$.

${ }^{15} \mathrm{Id}$.

${ }^{16} \mathrm{Id}$.
} 
Massachusetts' Workers' Compensation law provides that if a company has one or more employees, or the business is a corporation, the company must have Workers' Compensation insurance before employees begin.

\section{FIXING THE PROBLEM}

Six Michael Bianco Inc. workers from New Bedford filed a federal class-action lawsuit against Michael Bianco Inc. alleging they regularly worked 16-hour days - up to 80 hours a week - without being paid overtime. The class-action suit will cover more than 500 Bianco workers over a period of two years and will include former and current workers.

"Federal and state labor laws are enforceable whether the worker is legal or illegal", ${ }_{17}$ said Ms. Richardson, an attorney with Greater Boston Legal Services, which filed the suit on behalf of the workers. Ms. Richardson, however, would not comment on whether the workers were legal or illegal. "Michael Bianco Inc. withheld hundreds of thousands of dollars from low-wage workers, padding its profits at the expense of these workers and their families", said Phillip Kasssel, Advocacy Director for South Coastal Counties Legal Services. ${ }^{18}$

The civil suit filed in Federal District Court states that the company regularly and deliberately failed to pay workers their regular wages as required by federal and state law. The company illegally and deliberately failed to pay workers overtime by creating separate corporations to minimize the appearance of overtime worked. The company illegally failed to pay for all working time by making deductions from working time. The company failed to pay workers after the end of their shifts, even though they were required to stay longer at the factory. The workers request a jury trial and actual damages, multiple damages, punitive damages and reasonable attorney fees and costs. ${ }^{19}$

\section{CURRENT IMMIGRATION LAW}

The congressionally mandated Immigration Reform and Control Act (IRCA) reformed the United States Immigration Law. The Act made it illegal to knowingly hire or recruit illegal immigrants (immigrants who do not possess lawful work authorization), required employers to attest to their employees' immigration status, and granted amnesty to certain illegal immigrants who entered the United States before January 1, 1982 and had resided there continuously. The law criminalized the act of knowingly hiring an illegal immigrant and established financial and other penalties for those employing illegal aliens. The congressional intent was to reduce illegal immigration by reducing the prospects for employment for illegal immigrants. Employers were required to complete form I-9 in order to ensure that all employees presented documentary proof of their legal eligibility to accept employment in the United States.

Since 1986, under the Immigration Reform and Control Act (IRCA), employers may hire only persons who may legally work in the U.S.; i.e., citizens and nationals of the U.S., and aliens authorized to work in the U.S. The employer must verify the identity and employment eligibility of anyone to be hired.

\section{THE NEED FOR ADDITIONAL LEGISLATION}

On a Federal level, the U.S. Senate voted unanimously to bar companies that hire illegal immigrants from receiving federal contracts. The ban would last for seven years and would last 10 years if the company was caught hiring illegal immigrants while it held a federal contract. The ban could be lifted if the government decided that doing so was in the interest of national security. ${ }^{20}$

\footnotetext{
${ }^{17} \mathrm{Id}$.

${ }^{18}$ Gordon Law Group. Retrieved from www.gordonllp.com/news, June 12, 2007

${ }^{19}$ U.S. District Court District of Massachusetts, Class and Collective Action Complaint, Flor Chach, Elsy Hernandez, Digna Mendoza, Pedro Pacheco, Carlos Simaj Morente and Gilbert Vieira, on behalf of themselves and all others similarly situated Plaintiffs v. Michael Bianco Inc., Front Line Defense Inc., Francesco Insolia, Gloria Melo, Suzanne Thompson and Marguerite Insolia - Defendants.

${ }^{20}$ The Wall Street Journal. Senate Endorses A Contracts Ban. Jan 26, 2007. A.5
} 
Representative Brenda Landwehr (R-Wichita) introduced illegal immigration reform legislation in the 2008 session. This legislation included revoking the business license of and imposing civil penalties on any business found to have knowingly employed an illegal alien or failing to comply with Federal law regarding verification of an employee's legal citizenship/work status. ${ }^{21}$

On a state level, several states, such as North Carolina, have enacted legislation penalizing companies by disallowing economic development incentives to companies that employ unauthorized aliens, and prohibiting state and local government contracts with contractors who employ illegal immigrants. ${ }^{22}$ Representative Landwehr states, "I am a strong supporter and advocate of legal immigrants who choose to make Kansas their new home. I welcome them with open arms. They have come to this country through proper means and have followed our country and state's laws to do so. However, Kansas cannot continue to be a safe harbor for illegal immigrants." ${ }^{23}$

Colorado signed HB 1343 on 6/6/2006 which prohibits state agencies from entering into contract agreements with contractors who knowingly employ illegal immigrants and requires prospective contractors to verify legal work status of all employees. ${ }^{24}$

\section{PENALTIES}

As Francesco Insolia sat quietly waiting for the court proceedings to commence, he knew the harshness of the penalties. If convicted, Insolia could face a maximum sentence of six months in prison and a $\$ 3,000$ fine for each illegal alien hired by MBI on the conspiracy to hire illegal aliens charge and ten years in prison, to be followed by three years of supervised release and a $\$ 250,000$ fine on the conspiracy to encourage illegal aliens to reside in the United States charge. Torres faces a maximum sentence of 15 years in prison, to be followed by three years of supervised release and a $\$ 250,000$ fine.

In addition, the company faces $\$ 45,000$ in proposed fines, according to the U.S. Occupational Safety and Health Administration, for possible violations of workplace health and safety standards. "Among other violations, the company allegedly had failed to determine what protective equipment was needed for employees whose duties exposed them to hazardous chemicals and flying particles; failed to supply its workers with the required eye, face and hand protection; failed to provide hazardous material information and training; and failed safeguard against the accidental startup of machinery during maintenance. In addition, OSHA said the inspection found unguarded machinery and improperly used or guarded electrical wiring and equipment. ${ }^{25}$

\section{CONCLUSION}

The owner of the company, Francesco Insolia, and three managers (Ana Figueroa, Delia Costa, and Gloria Melo) were arrested on charges in connection with alleged hiring of illegal aliens. The criminal complaints included conspiring to encourage or induce illegal aliens to reside in the United States and conspiring to hire illegal aliens. Luis Torres was charged in a separate complaint with the knowing transfer of fraudulent identification documents. As a result of the arrests, hundreds of MBI employees will be interviewed to determine their immigration status. Aliens who were unlawfully in the United States were charged administratively and placed in removal proceedings.

According to the affidavits, it is alleged that Insolia maintains a work force of whom the majority are illegal aliens. It is further alleged that he intentionally seeks out illegal aliens because they are more desperate to find employment and are thus more likely to endure severe workplace conditions he has imposed. It is alleged that these conditions include docking of pay by 15 minutes for every minute an employee is late; fining employees $\$ 20$ for

\footnotetext{
${ }^{21}$ Representative Landwehr, retrieved at www.kansashouse.org on July 25, 2007

${ }^{22}$ General Assembly of North Carolina, Session 2007. Senate Bill 573 Restrict Contracts \& Benefits/Illegal Aliens, March 7 , 2007

${ }^{23} \mathrm{Id}$.

${ }^{24}$ National Conference of State Legislatures: State Legislation Related to Immigration, retrieved from www.ncsl.org/programs/immig, June 29, 2007

${ }^{25}$ Providence Business News, Michael Bianco faces \$45,000 in OSHA fines, July 6, 2007
} 
spending more than two minutes in the restroom and firing for a subsequent infraction; providing one roll of toilet paper per restroom stall per day, typically resulting in the absence of toilet paper after only 40 minutes each day; fining employees $\$ 20$ for leaving their work area before the break bell sounds; and fining employees $\$ 20$ for talking while working and firing for a subsequent infraction.

Francesco Insolia and Michael Bianco Inc. (MBI) were sentenced for various charges alleging they hired illegal aliens, helped to shield them from detection, failed to pay them full overtime, and fraudulently misled the government, all in an effort to maximize profits on a series of lucrative military contracts. MBI was ordered to pay a fine of $\$ 1.51$ million dollars and restitution of $\$ 460,000$ for overtime owed to employees. Its president and principal shareholder, Francesco Insolia, was sentenced to 12 months and one day imprisonment, to be followed by three years of supervised release and a $\$ 30,000$ fine.

MBI previously pled guilty to 18 counts of knowingly hiring illegal aliens on various dates between early 2004 and late 2006, a time during which the company grew from less than 100 to 500 employees; helping to harbor and shield illegal aliens from detection from authorities between 2004 and 2007; fraudulently misrepresenting Social Security numbers; committing mail fraud when it submitted Social Security numbers to the IRS and Social Security Administration knowing that many of the numbers had to be false given that many of the company's employees were illegal aliens; and failing to pay many employees overtime from 2005 to 2007. Insolia pled guilty to helping harbor and conceal aliens by allowing the company to submit false Social Security numbers for employees to the government as if they were real. ${ }^{26}$

\section{AUTHOR INFORMATION}

Lynn Ruggieri is an Associate Professor of Accounting at Roger Williams University. Her educational background includes- J.D. Southern New England School of Law, Dartmouth MA, 2008, M.S.T. Bryant College, Smithfield RI, 1991, M.B.A. Providence College, Providence RI, 1991, B.S. Bryant College, Smithfield RI, 1984. Her professional interests in research include U.S. Conversion to International Reporting Standards, Fraud Examination, Case Studies, and Business Valuation. Her teaching interests include Advanced Accounting, Auditing, International Accounting, Managerial Accounting, Financial Accounting, and Forensic Accounting.

\section{REFERENCES}

1. United States District Court, District of Massachusetts, retrieved from www.uscourts.gov

2. Official call of the Court, Barnstable Clerk's Office

3. Massachusetts Secretary of State, retrieved from www.sec.state.ma.us/cor/

4. Michael Bianco Inc, retrieved from www.michael-bianco.com,

5. New Bedford Factory's Managers Face Conspiracy, Illegal Hiring Charges. Providence Business News (March 7, 2007)

6. Scott Helman. State OK'd Grants to Firm Did Not Verify Workers' Status, Boston Globe (April 9, 2007)

7. The City of New Bedford Official Website, available at www.ci.new-bedford.ma.us/

8. US Department of Defense Contracts, retrieved from http://www.defenselink.mil/contracts/contract.aspx?contractid=2985

9. US Immigration and Customs Enforcement. Retrieved from www.ice.gov,

10. U.S. Department of Justice, United States Attorney Michael J. Sullivan District of Massachusetts, retrieved from www.usdoj.gov/usao/ma, June 12, 2007

11. Zinner, Karen Lee, Hundreds Nabbed in Raid. The Providence Journal (March 7, 2007) A1

12. Zinner, Karen Lee, Factory Raid Sparks Crisis for Families. The Providence Journal (March 8, 2007) A1

13. Zinner, Karen Lee, Jobs, but no Dignity. The Providence Journal (March 9, 2007) A1

14. Zinner, Karen Lee, Hundreds Nabbed in Raid. The Providence Journal (March 7, 2007) A1

15. Zinner, Karen Lee, Jobs, but no Dignity. The Providence Journal (March 9, 2007) A1

\footnotetext{
${ }^{26}$ Statement by United States Attorney Michael J. Sullivan and Bruce M. Foucart, special agent in charge for ICE's Office of Investigations in Boston.
} 
16. Massachusetts Secretary of State, retrieved from www.sec.state.ma.us/cor/ March 10, 2007

17. Zinner, Karen Lee, \& Mulligan John E. Factory Raid Fallout. The Providence Journal (March 22, 2007) A1

18. Zinner, Karen Lee, Bianco Workers Allege Violations. The Providence Journal (March 28, 2007) A1

19. Nicodemus, Aaron. Workers sue Michael Bianco Inc. for Overtime Wages. Southcoast Today (May 16, 2007

20. Gordon Law Group. Retrieved from www.gordonllp.com/news, June 12, 2007

21. U.S. District Court District of Massachusetts, Class and Collective Action Complaint, Flor Chach, Elsy Hernandez, Digna Mendoza, Pedro Pacheco, Carlos Simaj Morente and Gilbert Vieira, on behalf of themselves and all others similarly situated - Plaintiffs v. Michael Bianco Inc., Front Line Defense Inc., Francesco Insolia, Gloria Melo, Suzanne Thompson and Marguerite Insolia - Defendants..S Department of Labor, Immigration Reform and Control Act, retrieved at www.dol.gov, on June 17, 2007

22. The Wall Street Journal. Senate Endorses A Contracts Ban. Jan 26, 2007.

23. A. Representative Landwehr, retrieved at www.kansashouse.org on July 25, 2007

24. General Assembly of North Carolina, Session 2007. Senate Bill 573 Restrict Contracts \& Benefits/Illegal Aliens, March 7, 2007

25. National Conference of State Legislatures: State Legislation Related to Immigration, retrieved from www.ncsl.org/programs/immig, June 29, 2007

26. 29 U.S.C $\$ 203$

27. IRS Publication 15, Circular E

28. Payroll Taxes, retrieved from www.Mass.gov. June 17, 2007

29. Census information retrieved at www.census.gov, June 20, 2007

30. Darryl Fears, Illegal Immigrants Targeted by States Impasse on Hill Spurs New Laws, The Washington Post, June 25, 2007; A1

31. Providence Business News, Michael Bianco faces $\$ 45,000$ in OSHA fines, July 6, 2007

32. Zinner, Karen Lee, Factory Raid Sparks Crisis for Families. The Providence Journal (March 8, 2007) A1

33. Washington Post May 14, 2005; A20

34. US Immigration and Customs Enforcement. Retrieved from www.ice.gov, June 2, 2007 


\title{
APPENDIX
}

\section{INSTRUCTOR'S MANUAL}

\section{CASE SYNOPSIS}

Michael Bianco Inc.was a relatively small manufacturing firm employing 85 people in 2001. By 2004, the company was awarded several multimillion dollar government contracts from the department of defense making backpacks for troops serving in Iraq. The company increased its work force to over 500 to accommodate the contracts. The workers, however, were illegal aliens. The department of homeland security raided the manufacturing facility and found and detained, for deportation, over 300 illegal workers. Further investigation revealed deplorable and unfair working conditions, including lack of heat and docking worker's pay for talking. Employees worked double shifts and instead of being paid overtime, they were paid straight time out of two separate companies. Humanitarian groups defended the workers and some later filed suit for back pay.

\section{COURSES AND LEVELS FOR WHICH CASE IS INTENDED}

Courses: Small Business Management, Entrepreneurship, Labor Relations

Level: Undergraduate

\section{TEACHING OBJECTIVES}

\author{
1. Ethical decision-making \\ 2. Management \\ 3. Labor Relations
}

\section{KEY ISSUES}

The main pedagogical objective of the case is to help students incorporate ethical considerations in business decisions, including ethical considerations on both sides of the immigration issue. This case is designed to present students a situation where they can evaluate ethical decision-making in a given situation for a company that may have grown too fast and could not keep up with the contracts it was awarded by the federal government.

\section{THEORY}

The definition of ethics is simply a system of moral principles. In order to apply these moral principles, many textbooks in Business and Management look to models of ethical reasoning. The models most frequently presented include the following:

\section{The Utilitarian Approach}

The utilitarian approach is one that provides the most good or does the least harm. The ethical action is the one that produces the greatest good and does the least harm for all who are affected, including customers, employees, shareholders, and the community. The utilitarian approach deals with consequences. The focus is to increase the good done and to reduce the harm done.

Considering the Bianco Company, the issue is whether to employ illegal aliens. Under the utilitarian approach, one would try to determine whether using these workers would result in the greatest good. If Bianco is employing the workers in response to price competition, it might enable Bianco to retain its market share, enabling the company to avoid laying off employees, and perhaps even allowing the company to pay higher wages. If Bianco refused to use the foreign workers, it may be unable to compete for the government contracts which could lead to a demise of the company. On the other hand, using illegal workers who may be working at wages lower than normal, may lower the wages of most workers, thus reducing almost everyone's standard of living and depressing the economy.

\section{The Rights Approach}

Under this approach, the ethical action is the one that best protects and respects the moral rights of those affected. This approach asserts that human beings have fundamental rights and liberties, such as freedom of consent, privacy and due process. Moral or ethical decisions are those that best maintain the rights of those people affected by them. An ethical decision is one that avoids interfering with the fundamental rights of others. 


\section{Justice Approach}

Early Greek philosophers maintained the idea that like individuals should be treated equally. Currently, this notion would be updated to mean that ethical actions should treat all individuals equally and if they cannot be treated equally there should be some measurable standard to attempt to do so (e.g. payments of higher salary for greater contribution to the organization).

\section{The Common Good Approach}

Early Greek philosophers maintained the idea that life in community is good and actions should contribute to and enforce that notion. This analysis implies that societal relationships are the basis of ethical reasoning and that respect and compassion for all others, especially those who are vulnerable, are requirements under this approach. This concept approach highlights the common conditions that are significant to the welfare of all persons.

\section{The Virtue Approach}

The virtue approach to ethics is that ethical actions should be consistent with certain ideals that contribute to the development of humanity. These ideals enable individuals to act according to the highest character. These ideals or virtues include the concepts of honesty, courage, compassion, generosity, tolerance, fidelity, integrity and fairness.

The topics and questions listed below should be evaluated in terms of the ethics models listed above by asking the following questions:

- What action will produce the most good and do the least harm? (Utilitarian Approach)?

- What action most respects the rights of all involved? ( Rights Approach)?

- What action treats people equally or proportionately? (Justice Approach)?

- What action best serves the community as a whole, not just some members? (Common Good Approach)?

- What action leads one to act with the highest virtues? (Virtue Approach)?

\section{RESEARCH METHODS}

This case was written based on materials available in the public record, including corporate filings, arrest reports, government press releases from Immigration Customs and the Department of Justice, human rights organizations, press reports, and documents in connection with a lawsuit brought by the workers of Michael Bianco Inc. against the company and the owners in U.S. District Court, including motions and briefs filed by both parties and judicial decrees.

\section{DISCUSSION QUESTIONS}

1. Did the owner get in over his head with a firm-fixed-price contract? What are the advantages and disadvantages of a firm-fixed-price contract and a cost-plus contract?

A firm-fixed-priced contract provides for a price that is not subject to any adjustment on the basis of the contractor's cost experience in performing the contract. This contract type places upon the contractor maximum risk and full responsibility for all costs and resulting profit or loss. It provides maximum incentive for the contractor to control costs and perform effectively and imposes a minimum administrative burden upon contracting parties.

Cost-plus type contracts provide for payment of allowable incurred costs, to the extent prescribed in the contract. The contracts establish an estimate of total cost for the purpose of obligating funds and establishing a ceiling that the contractor may not exceed (except at own risk) without the approval of the contracting officer.

Cost-plus contracts are suitable for use only when uncertainties involved in contract performance do not permit costs to be estimated with sufficient accuracy to use any type of fixed price contract.

Should the business owner be aware and know at all times what the company was undertaking or did the government take advantage of an owner that had not ventured into this product line before and lock the company into an unreasonable and unattainable objective? 


\section{Did the state and city condone the hiring of illegal workers?}

The city of New Bedford clearly knew the makeup of its population, which is stated on their website. There are a great many immigrants in the city. The city and state provided grant and tax relief in return for the company providing jobs. There were no restrictions on the workers that were to be hired when the grant was given to Bianco Inc. The company did provide the jobs and therefore maintained its part of the agreement. Should it have been understood that illegal aliens were not part of the package or should the city of New Bedford specifically spell out the restriction?

\section{Are the workers to blame?}

The workers detail the sweatshop conditions, but what is not readily apparent from the information provided is that the workers are actually paid $20 \%$ more than the average legal worker because they do not pay payroll taxes. A worker stated that for 40 hours work at $\$ 7.50$ per hour, she received a net pay of $\$ 279$. If the proper taxes were withheld, and paid that worker should have received a net pay of $\$ 218.55$. The workers are clearly receiving a benefit, even with deductions to their pay.

\begin{tabular}{|l|c|}
\hline \multicolumn{2}{|c|}{ Gross Pay: 40 hours at \$7.50 per hour $=\$ \mathbf{3 0 0}$} \\
\hline \multicolumn{2}{|c|}{ The following payroll taxes are applicable: } \\
\hline FICA & $\$ 18.60$ \\
\hline Medicare & $\$ 8.70$ \\
\hline Federal Income Tax & $\$ 43.00$ \\
\hline State Income Tax & $\$ 11.15$ \\
\hline Total Withholding & $\$ 81.45$ \\
\hline Net Pay After Withholdings & $\$ 218.55$ \\
\hline
\end{tabular}

The workers were not the only ones saving on payroll taxes. Also of note are the taxes which are not paid by Bianco Inc. or Front Line Defense on the same wages because the company should have matched the employee contribution.

The taxes due consist of:

\begin{tabular}{|l|l|}
\hline FICA & $\$ 18.60$ \\
\hline Medicare & $\$ 8.70$ \\
\hline FUTA & $\$ 2.40$ \\
\hline SUTA & $\$ 18.12$ \\
\hline Total Payroll Taxes Not Paid & $\$ 47.82$ \\
\hline
\end{tabular}

4. Is there a need for additional legislation - federal or state?

Additional federal legislation to bar companies that hire illegal immigrants from federal contracts should not be necessary if the 1986 IRCA was followed as enacted. If federal contracts are only awarded to firms that have documented workers, how will this be monitored and, more significantly, what is the cost, and which party should incur the cost? The contract with Michael Bianco Inc. was a firm-fixed contract that places the risk of cost increases on the contractor as opposed to the government. IRCA has already mandated that workers should be documented by the employer and the Michael Bianco Inc. raid verifies that it was not done. The very language of the ban, in that it will bar companies that hire illegal immigrants from receiving federal contracts, indicates that hiring illegal workers is currently the norm.

Legislation is also being considered at the state level. Frustrated with Congress' inability to pass an immigration overhaul bill, state legislatures are considering or enacting a record number of strongly worded proposals targeting illegal immigrants. ${ }^{27}$ These laws limit illegal immigrants' ability to obtain jobs, find housing, get driver's licenses and receive many government services. They also empower state law enforcement agencies to inquire into an immigrant's

${ }^{27}$ Darryl Fears, Illegal Immigrants Targeted by States Impasse on Hill Spurs New Laws, The Washington Post, June 25, 2007; A1 
legal status and hold for deportation those deemed to be here illegally. ${ }^{28}$ These state laws impact two areas: 1) Companies may encounter difficulties in staffing positions in areas where there is not significant availability of a workforce. 2) If states, such as North Carolina and Colorado, disallow economic development incentives prohibiting state and local government contracts with contractors who employ illegal immigrants, doing business will have a higher cost and will in turn impact negatively on the economy.

\section{Additional Issues}

- The failure of legislation to distinguish between businesses operating at more than one location that could be shut down because of multiple infractions by a different branch of the business

- Possible discrimination which could become a problem as employers try to avoid hiring illegal immigrants

- Jobs frequently held by illegal immigrants in fields and factories would be left vacant.

- The ability of local officials and police to enforce the legislation without falling into racial profiling and discrimination

5. Is the punishment for the company too harsh?

If convicted, Insolia, Figueroa, Costa, and Melo each face a maximum sentence of six months in prison and a $\$ 3,000$ fine for each illegal alien hired by MBI on the "conspiracy to hire illegal aliens charge, and 10 years in prison, to be followed by three years of supervised release and a $\$ 250,000$ fine on the conspiracy to encourage illegal aliens to reside in the United States' charge. Torres faces a maximum sentence of 15 years in prison, to be followed by three years of supervised release and a $\$ 250,000$ fine.

In addition, the company faces $\$ 45,000$ in proposed fines, according to the U.S. Occupational Safety and Health Administration, for possible violations of workplace health and safety standards. Among other violations, the company allegedly had failed to determine what protective equipment was needed for employees whose duties exposed them to hazardous chemicals and flying particles; failed to supply its workers with the required eye, face and hand protection; failed to provide hazardous-material information and training; and failed to safeguard against the accidental startup of machinery during maintenance. In addition, OSHA said, "the inspection found unguarded machinery and improperly used or guarded electrical wiring and equipment." 29

The penalties are substantial for the owner of the company, yet there was a government inspector on the premises. Did this inspector have any responsibility to notice the conditions and workers?

\section{Is Amnesty the answer?}

Sen. Kennedy, joint sponsor of the 2005 McCain-Kennedy immigration reform bill, said, "The raid further highlights the immediate need for reform of our broken immigration system. We need to hold businesses accountable for the status and treatment of workers they hire and the best way to end the exploitation of undocumented workers is to put them on a path to earn legal status." 30

The McCain-Kennedy bill would establish a worker visa program that would allow employers to temporarily hire foreign citizens to fill jobs that cannot be filled with U.S. laborers. The bill also proposes to allow individuals unlawfully in the US. to remain and become citizens by paying a $\$ 1,500$ fine. Will this amnesty encourage illegal entry by invalidating current immigration laws like IRCA?

The bills' authors argue that this is not an amnesty because it requires recognition of wrongdoing. They also argue that establishing the temporary visa will prevent a new pool of illegal immigrants from arriving because it will become politically realistic to fine employers who continue to employ illegals. Most of all, this provision for illegal immigrants makes sense because any legislation that does not deal with the approximate 10 million illegals will ultimately result in more lawbreaking.31

The alternative point of view is, "It is understandable that many from around the globe would want to come to live, work and raise families here in the greatest democracy in the world. However, this must be done in compliance with

\footnotetext{
${ }^{28}$ Id.

${ }^{29}$ Providence Business News, Michael Bianco faces \$45,000 in OSHA fines, July 6, 2007

${ }^{30}$ Zinner, Karen Lee, Factory Raid Sparks Crisis for Families. The Providence Journal (March 8 , 2007) A1

${ }^{31}$ Washington Post May 14, 2005; A20
} 
U.S. immigration laws - not in violation of them", commented U.S. Attorney Sullivan. "Employer accountability is essential to ensuring the integrity of the nation's immigration system and knowingly hiring illegal immigrants is a violation of law, plain and simple, and those responsible will be prosecuted." ${ }^{32}$

"Unlawful employment is a powerful magnet driving illegal immigration", said Assistant Secretary Myers. "Egregious hiring practices, widespread use of fraudulent documents, and blatant disregard for the rule of law made this case a priority for ICE." ${ }^{33}$

7. Are these the jobs that nobody wants?

Based on an analysis of the statistical census information for just the city of New Bedford, Massachusetts, the location of Michael Bianco Inc., it would appear that there was a significant labor pool to draw from. It also appears from the fact that workers within the company assisted illegal aliens in obtaining Social Security numbers and green cards that the company did not attempt to hire other than illegal aliens.

8. Can the illegal workers sue?

Yes. Anyone can bring suit in US court as long as the court has jurisdiction to hear the case. The Federal District court in Boston, where the action was filed, has jurisdiction to hear the case because the matter involves federal law. The court has personal jurisdiction over the Defendant, Michael Bianco Inc., because the company does business in the state. The fact that the Plaintiffs in this case are not citizens is not relevant.

The workers did knowingly take the job. They knowingly were illegal in the country. Should they be allowed to use the laws and court system of the US to obtain back pay? Should the workers be required to pay back payroll taxes?

9. $\quad$ Ethical Implications

There are ethical considerations on both sides of the issue. Corporate citizens should not intentionally hire illegal workers and exploit their vulnerable situation. The workers employed at the company should not be purchasing Social Security numbers or Green Cards.

What the company has done is illegal. In their quest to lower costs, they violated immigration laws, ignored federal payroll laws, labor laws, and ran the plant as a sweatshop taking advantage of the idea that illegal aliens would not complain. It appears that the company took on too much in accepting government contracts and possibly underestimated the costs to produce the product. In an effort to reduce the cost of payroll, the company hired illegal aliens.

\footnotetext{
${ }^{32}$ US Immigration and Customs Enforcement. Retrieved from www.ice.gov, June 2, 2007

${ }^{33} \mathrm{Id}$.
} 